\title{
Editorial
}

\section{eCAM: Darwin and Metchnikoff}

\section{Edwin L. Cooper}

Laboratory of Comparative Neuroimmunology, Department of Neurobiology, David Geffen School of Medicine at UCLA University of California, Los Angeles, CA 90095-1763, USA

Darwin and Metchnikoff exerted prescient influences on biology and medicine. Is this seemingly an unlikely pair to be juxtaposed and mentioned in a journal devoted to evidence-based complementary medicine? I think not. I will try and persuade you from a few viewpoints why I accord them this place. First, it seems essential that all biologists, biomedical specialists and everyone, with a general cultural awareness, should at least recognize their names (surely Darwin!). Second, for the biologists, Darwin is even more familiar since this is his year, the 150th anniversary of the publication of On Origin of Species (disciplines embraced: genetics, evolution, ecology, ethology, anthropology and natural history). He is receiving well-deserved coverage in mass media and scientific publications; even in $e C A M$, there is an invited peer-reviewed commentary on his experimentation with homeopathy (1). Darwin also authored a book on the behavior of earthworms (2) so very popular with fisherman but of really greater significance to ancient medical practices as related to inflammation. Earthworms are referred to as DiLong in the compendium of Traditional Chinese Medicine (TCM) and they are essential in Ayerveda (3) and Kampo (4). Metchnikoff is similarly prescient for biologists [disciplines embraced are embryogenesis, inflammation, immunity, aging, pathology and philosophy $(5,6)]$. Metchnikoff also did experiments on himself as guinea pig with alternative therapies, especially in his quest to defer aging; he was an adherent of probiotics (7).

When we think of Darwin, his famous voyage on The Beagle comes to mind, along with his observations of birds on the Galapagos Islands. No one ever

For reprints and all correspondence: Edwin L. Cooper, Laboratory of Comparative Neuroimmunology, Department of Neurobiology, David Geffen School of Medicine at UCLA University of California, Los Angeles, CA 90095-1763, USA. Tel: +1 310825 9567; Fax: +1 310825 2224; E-mail: ecam@mednet.ucla.edu brings up or even knows about the time that he spent studying earthworms. Early on in his career, the work on earthworms occupied him as much as or even more than his perseverance and contributions to the question of evolution. His analyses of earthworms resulted in the publication in 1881 of his book, The Formation of Vegetable Mould Through the Action of Worms, with Observations on their Habits $(2,8)$. Apparently it sold as many copies or even more than On the Origin of Species. Although not consistent, there were two phases of his career devoted to earthworms, only temporarily interrupted by his quest to understand evolution. His work on these earthly dwellers was viewed by many as seminal, since much of our world did not focus on ecological and agricultural advantages they afforded. Of course, this Eurocentric view neglected the place that earthworms occupied as antecedents of certain CAM practices, i.e. their role in ancient medical practices (9). A revival is under way, but with a view toward indicating the role of earthworms. Our quest for more solid evidence is crucial, if this discipline is to advance and flourish. Metchnikoff's work, especially on marine creatures, figured prominently in laying the ground work for the relatively unexplored area of bioprospecting first published in eCAM by Müller et al. (10), later extended by Cooper (11-13) and Nigam et al. (14).

Nobel prize-winning Russian zoologist Elie Metchnikoff is the first basic scientist who explored the first-hand possible benefits of fermented foods to health. His inspiration came from observations that Bulgarians had an average lifespan of $\sim 90$ years, an exceptional age for the early 1900s. Moreover, four of every thousand lived past 100 years of age. One possible clue was their significant differences in diet, i.e. they consumed large amounts of fermented milks. In another group looked at more recently, the famous Hunzas of Kashmir and the Georgians (formerly of the Soviet Union) have

(C) The Author(s) 2009. Published by Oxford University Press.

This is an Open Access article distributed under the terms of the Creative Commons Attribution Non-Commercial License (http://creativecommons.org/ licenses/by-nc/2.5/uk/) which permits unrestricted non-commercial use, distribution, and reproduction in any medium, provided the original work is properly cited. 
captured attention due to their longevity; their males over 100 years old participate in horse events, e.g. polo, and women of equal age work in fields. It is noteworthy that a significant dietary component of theirs consists of fermented milks, using active Lactobacilli bacteria. Metchnikoff gave the name Bulgarian bacillus to the bacteria that he believed to be responsible for long life. This is now called Lactobacillus bulgaricus. As a result, Metchnikoff is often revered as The Father of Probiotics (15).

A recently published book even promises to bring Darwin solidly into the realm of importance for medical doctors (16). Peter T. Ellison reviews the book (17) and according to Science, 'it is the first specifically designed as a textbook appropriate for medical students and medical schools, and it succeeds brilliantly'. According to Ellison (17), 'Evolutionary science is critical to an understanding of integrated human biology and is increasingly recognized as a core underpinning discipline by medical and public health professionals. Advances in the fields of genomics, epigenetics, developmental biology and epidemiology have led to the growing realization that incorporating evolutionary thinking is essential for medicine to achieve its full potential. This is the first integrated and comprehensive textbook to explain the principles of evolutionary biology from a medical perspective and to focus on how medicine and public health might utilize evolutionary biology. It is written in a style which is accessible to a broad range of readers, whether or not they have had formal exposure to evolutionary science.'

Principles of Evolutionary Medicine is divided into three sections: the first provides a systematic approach to the principles of evolutionary biology as they apply to human health and disease, using examples specifically relevant to medicine. It incorporates chapters that present evolutionary processes, molecular evolution, evolution of humans, life history theory and evolutionarydevelopmental biology. The second part illustrates the application of these principles to understand nutrition and metabolism, reproduction, combating infectious disease and stress and human behavior. The final section provides a general framework to show in practical terms how the principles of evolutionary medicine can be applied in medical practice and public health. 'This novel textbook provides the necessary means for medical doctors and other health professionals, medical students and biomedical scientists, as well as anthropologists interested in human health, to gain a better understanding of the evolutionary processes underlying human health and disease' (18).

So in 2008-09, we celebrate them - the centennial anniversary of the Nobel Prize in Physiology and Medicine to
Metchnikoff (19) and 150 years since Darwin's famous book. $e C A M$ has to some extent followed in the paths of these two giants of biology in our vision for renewed bioprospecting. Darwin led us into the field and Metchnikoff into the laboratory $(20,21,22)$.

\section{References}

1. Ullman D. The curious case of Charles Darwin and homeopathy. Evid Based Complement Alternat Med 2009;6.

2. Darwin C. The Formation of Vegetable Mould through the Action of Worms with Some observations on their Habits. London: John Murray, 1881 .

3. Balamurugan M. Restoration of histoarchitecture in the paracetamolinduced liver damaged rat by earthworm extract, Lampito maurito (Kinberg). Eur Rev Med Pharmacol Sci 2007;11:407-11.

4. Matsuba S. Complementary and alternative approaches to biomedicine. Evid Based Complement Alternat Med 2004;1:345-8.

5. Besredka A. The Story of an Idea (Rivenson A, Oestreicher R, trans.). Bend, OR: Maverick, 1979.

6. Tauber AI, Chernyak L. Metchnikoff and the Origins of Immunology: From Metaphor to Theory. New York: Oxford University Press, 1991.

7. Vasiljevic T, Shah NP. Probiotics - from Metchnikoff to bioactives. Int Dairy J 2008;18:714-28.

8. Feller C, Brown GG, Blanchart E, Deleporte P, Chernyanski SS, Darwin C. Earthworms and the natural sciences: various lessons from past to future. Agric Ecosyst Environ 2003;98:29-49.

9. Cooper EL, Ru B, Weng N. Earthworms: sources of antimicrobial and anticancer molecules. In: Cooper EL, Yamaguchi N (eds). Complementary and Alternative Approaches to Biomedicine. New York: Kluwer Publishers, 2004, 359-90.

10. Müller WEG, Schröder HC, Wiens M, Perovic-Ottstadt S, Batel R, Müller IM. Traditional and modern biomedical prospecting: Part II - the benefits: approaches for a sustainable exploitation of biodiversity (secondary metabolites and biomaterials from sponges). Evid Based Complement Alternat Med 2004;1:133-44.

11. Cooper EL. Drug discovery, CAM and natural products. Evid Based Complement Alternat Med 2004;1:215-17.

12. Cooper EL. Bioprospecting: a CAM Frontier. Evid Based Complement Alternat Med 2005;2:1-3.

13. Cooper EL. CAM, eCAM, bioprospecting: the 21st century pyramid. Evid Based Complement Alternat Med 2005;2:125-27.

14. Nigam $Y$, Bexfield A, Thomas S, Ratcliffe NA. Maggot therapy: the science and implication for CAM Part II-maggots combat infection. Evid Based Complement Alternat Med 2006;3:303-8.

15. Podolsky S. Cultural divergence: Elie Metchnikoffs' Baciillus bulgaricus therapy and his underlying concept of health. Bull Histo Med 1998;72:1-27.

16. Gluckman P, Beedle A, Hanson M. Principles of Evolutionary Medicine. New York: Oxford University Press, 2009.

17. Ellison PT. Evolutionary biology for doctors. Science 2009;324: 1207.

18. Pennisi E. Darwin applies to medical school. Science 2009;324: $162-163$.

19. Heifetz L. Centennial of Metchnikoff's discovery. J Reticuloendothel Soc 1982;31:381-91.

20. Cooper EL, Kauschke E, Cossarizza A. Digging for innate immunity since Darwin and Metchnikoff. Bioessays 2002;24: 319-33.

21. Cooper EL. From Darwin and Metchnikoff to Burnet and beyond. In: Egesten A, Schmidt A, Herwald $\mathrm{H}$ (eds). Trends in Innate Immunity. Switzerland: Karger, Basel, 2008, 1-11.

22. Cooper EL. Evolution of immune systems from self not self to danger to artificial immune systems (AIS) Physics of Life (in press). 


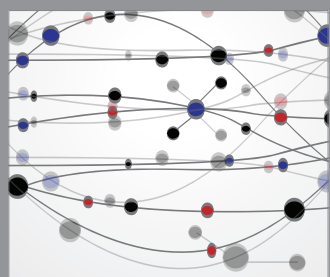

The Scientific World Journal
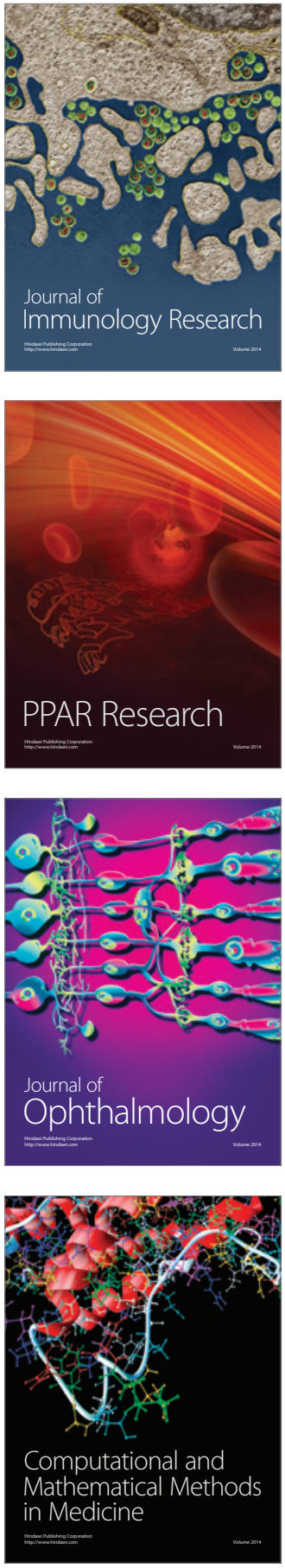

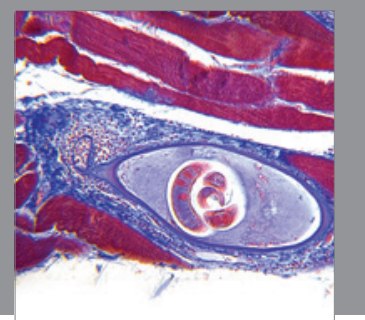

Gastroenterology

Research and Practice
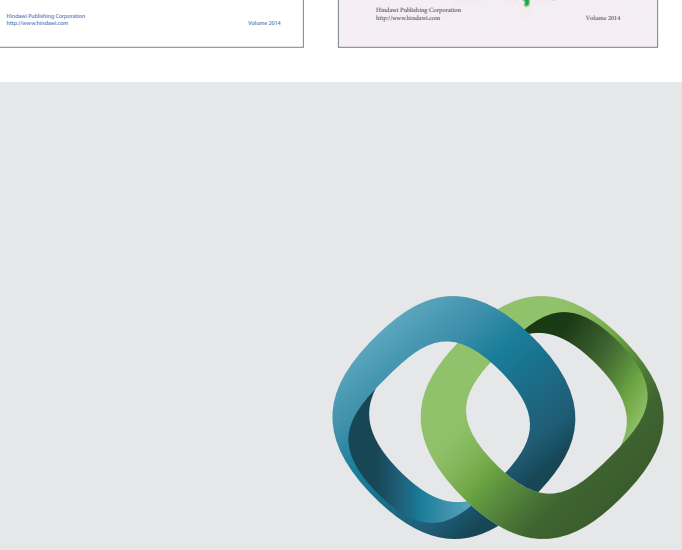

\section{Hindawi}

Submit your manuscripts at

http://www.hindawi.com
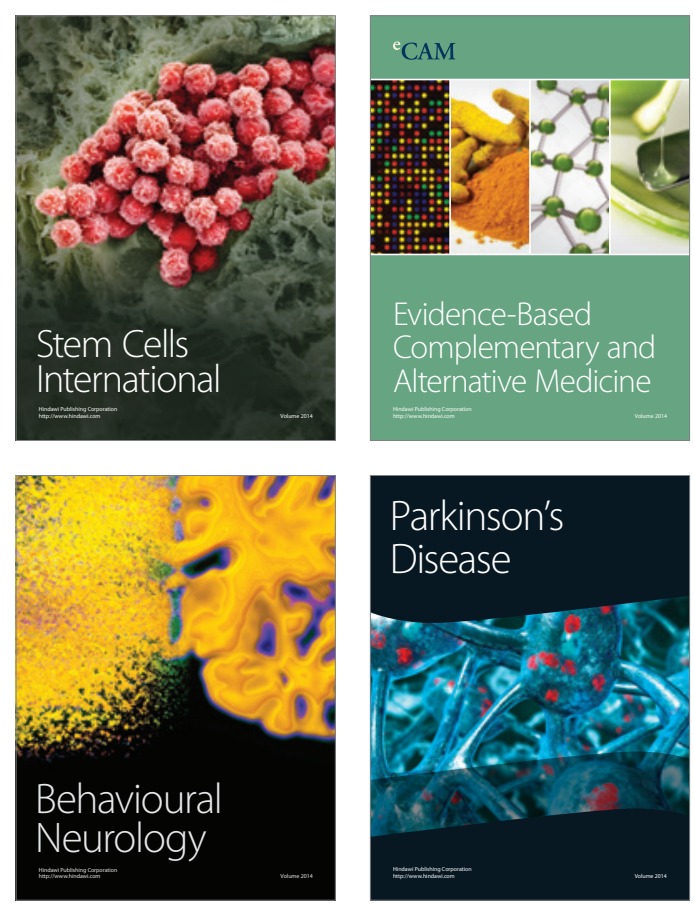

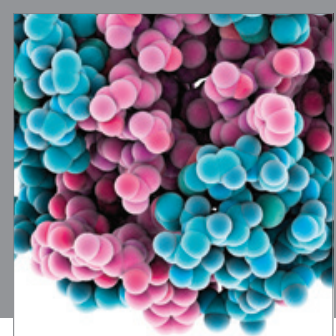

Journal of
Diabetes Research

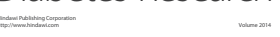

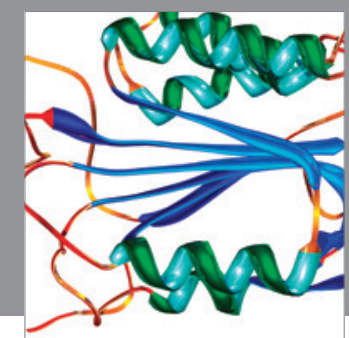

Disease Markers
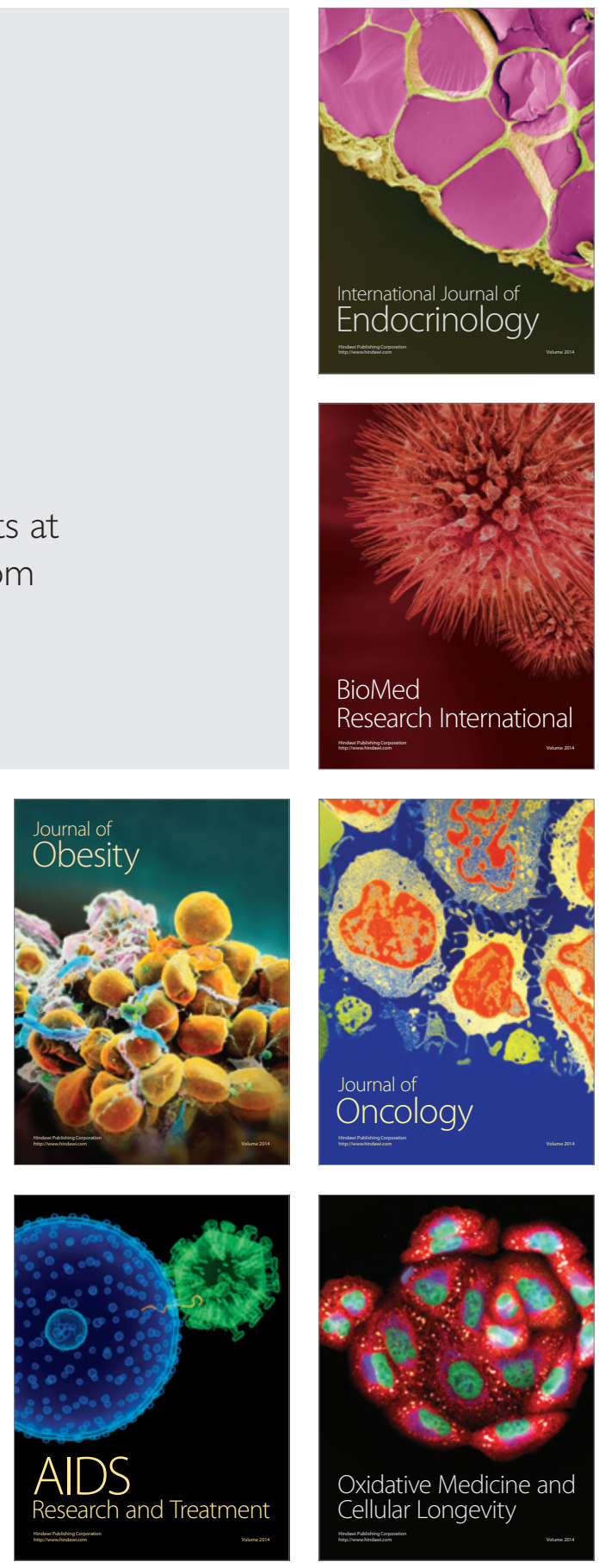